\title{
Koerad Eesti asukate viikingiaja maailmapildis
}

Tõnno Jonuks

\begin{abstract}
Teesid
Loomade positsiooni seoses teispoolsuskujutelmadega on arheoloogid seni kahetsusväärselt vähe uurinud. Küll aga pakub Eesti arheoloogiline materjal tõlgendamiseks piisavalt põnevat ainest, näiteks viikingi- ja hilisrauaaegsed koerakujukesed ning koertematused. Käesolevas vaatangi Eesti muinasajast pärit koerakujukesi ja koeraluude panustamist kalmesse ning võrdlen neid erinevate usundilooliste interpretatsioonidega. Tundub, et koerte panustamine kalmetesse viikingiajal on seotud kujutlusega teispoolsusest kui eraldi maailmast.
\end{abstract}

Märksõnad: arheoloogia, kalmed, koerad, muinasusund, teispoolsus

\section{Sissejuhatus}

Koera ühendab inimesega pikk ajalugu. Selle kooseksisteerimise analüüsimisel on uurijad tavaliselt esile tõstnud vastastikuse kasu printsiipi, rõhutades koera abi ja kasulikkust nii küttidele kui ka karjakasvatajatele. Mööda pole pääsetud ka koerast kui valvurist. Samuti leidub uurijaid, kes on tähtsustanud koera rolli vaimses maailmas või on viidanud koerale kui ohvriloomale. Kuid miks ohverdati koer - loom, kelle praktiline ja emotsionaalne väärtus olid piisavalt suured? Milliseid tähendusi võisid inimesed mingil konkreetsel perioodil veel koerale omistada? Miks on koer ainus loom, keda Eestis on inimestega koos maetud?

\section{Koer jääaja lõpust kuni viikingiajani}

Koerad on Eesti elanike vanimad loomadest kaaslased, kes jooksid juba koos esimeste jääajajärgsete asukatega. Vanimad koeraluud pärinevadki Eesti seni teadaolevalt vanimast, Pulli asulast Sindi jõe kaldal 9000.-8550. aastast eKr (Jaanits \& Laul \& Lõugas et al.

http://haldjas.folklore.ee/tagused/nr31/jonuks.pdf 


\section{Tõnno Jonuks}

1982: 32). Sealsed koerad olid turjakõrgusega 55-65 cm ja kehaehituselt tõenäoliselt tänapäevaste laikade sarnased. Selle aja koerad olid peamiselt jahikoerad, ehkki ilmselt neid nälja korral ka söödi. Kas koerte jahirolli või mingite muude funktsioonide tõttu on juba mesoliitikumist alates teiste loomade hulgas erandlikult hakatud koeri ka matma. Eestist selliseid juhtumeid teada ei ole. Lähimad kiviaegsed koeramatused on pärit Põhja-Lätist Zveinjeki kalmistu mesoliitilises osas; ka Lõuna-Rootsi Skateholmi mesoliitilistest kalmistutest on leitud koeramatuseid - seal on koer maetud kas koos inimesega või ka eraldi hauda, kuid ilmses seoses inimestega (vt Nilsson Stutz 2003: 232, lisa 102). Skateholmi koeri on peetud äärmiselt olulisteks loomadeks. Nii nagu inimestele, pandi neilegi hauda kaasa panuseid või kaeti laip ookriga (Larsson 2000: 91).

Lisaks koertematustele kalmistuil ja koeraluudele kiviaegsetes asulates on kogu kiviajast teada arvukalt koertehammastest ripatseid alates mesoliitilistest asulatest ja lõpetades neoliitiliste matustega Tamulas, Jaluksel, Kõnnus jm (Kriiska \& Tvauri 2002: 61). Koerahammastest ripatsid ei olnud levinud ainult Eestis, vaid see oli omane kogu Põhja-Euroopa hilismesoliitikumile ja neoliitikumile (vt Zagorska \& Lõugas 2000), kusjuures põhiosa sellistest ripatsitest kuulub kesk- ja hilisneoliitikumi (Eriksson \& Lõugas \& Zagorska 2003: 52).

Seega saavutasid koerad kiviajal inimeste hulgas olulise koha. On väheusutav, et see piirdus vaid lemmikloomaks olemisega. Tõenäoliselt oli üheks põhjuseks koerte tähtsus jahil ja sealtkaudu koera kui esimese inimese juures püsivalt elava looma teistsugune sümboolne roll (loom, kes elas inimese juures ja keda mitte esimeses järjekorras nahka ei pistetud). Ilmselt sellest sümboolsusest tulenesid ka põhjused, miks koeri hakati matma ja miks kasutati koerahambaid ripatsitena. On ju kõikidel loomaliikidel, kelle hambaid või kihvu on ripatsitena kasutatud, olnud inimeste vaimses maailmapildis oma sümboolne roll.

Kui läbi kogu kiviaja on võimalik jälgida koera erilist rolli ja selle tähtsustamist inimmatuste juures, siis kiviaja lõpul nöörkeraamika perioodil (3200-800 aastat eKr) tekkis järsk muutus. Ilmselt leidsid sel ajal aset mitmed olulised teisenemised inimeste vaimses maailmas ja religioonis. Praeguses kontekstis pakub huvi see, et enam ei ole kasutatud loomahammastest ripatseid, seega puuduvad ka koerahammastest ripatsid. Loomulikult ei tähenda see, 
Tõnno Jonuks

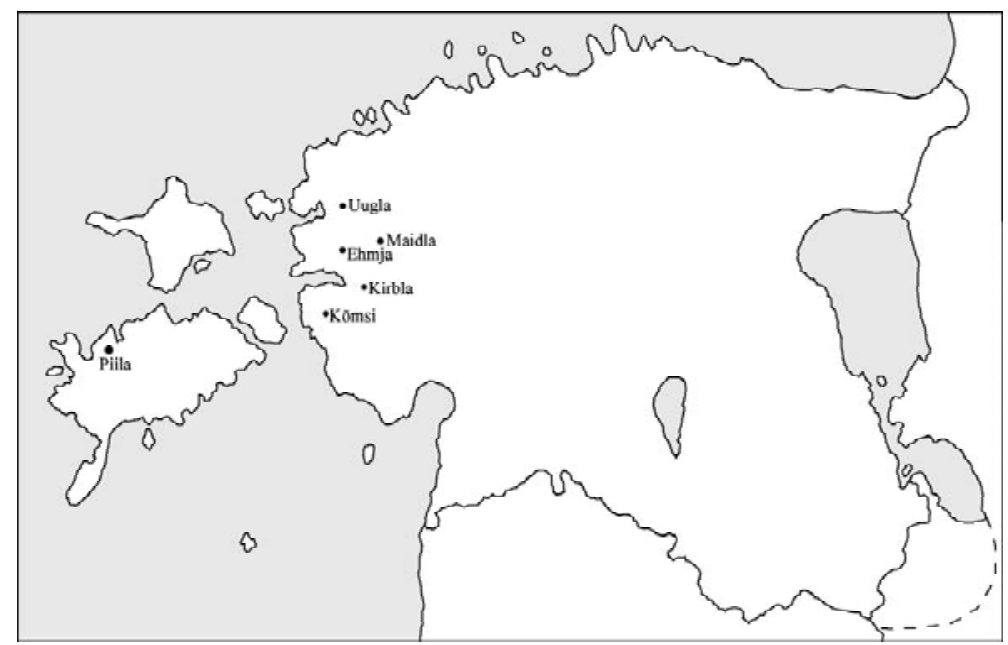

Joonis 1. Artiklis mainitud Eesti kalmed, kust on leitud viikingija hilisrauaaja koerte matuseid.

nagu poleks koerad enam inimeste juures elanud. Ehkki koerte roll jahikaaslasena ei olnud enam nii suur kui varem, elasid ka põlluharijate ühiskondades inimese kõrval koerad. Nii on koerad esindatud Asva noorema pronksiaja kindlustatud asula materjalis (Maldre 2003b), kus suurem osa loomaluudest kuulub kodu-, mitte metsloomadele (Kriiska 2004: 190). Ilmselt oli selleks ajaks teisenenud koera roll ja temast oli saanud pigem karjavaht.

Pronksiajast alates on meie peamised andmed pärit kivikalmetest. Eesti kivikalmete arheozooloogilist materjali on üsna põgusalt uuritud (vt Maldre 2003a: 263) ja üsna hilise ajani on piirdutud tõdemusega leitud loomaluudest ja nende liigilisest koosseisust. Seega on vanemate allikmaterjalidega ees veel kõvasti tööd, uuemate uuritud kalmete loomaluid analüüsitakse juba põhjalikumalt. Seega võivad siin esitatavad seisukohad põhjalikemate analüüside käigus muutuda, kuid praegu tundub, et see ei kummuta järgnevalt esitatava materjali põhilisi seisukohti. Oma osa loomaluude analüüsimise raskustes on kindlasti ka suurel hulgal põlenud loomaluudel, mis muudavad raskeks, kui mitte võimatuks liigi määramise.

Nii kivikirstkalmetes (Kraut 1985) kui ka tarandkalmetes, seega perioodil 11. saj eKr kuni 5. saj pKr, leidub loomaluid. Ülekaalus on loomulikult "toiduloomad", põhiliselt kits/lammas, veis ja 


\section{Tõnno Jonuks}

siga, metsloomadest enim jänes, mõnevõrra ka põder ning mereäärsetes piirkondades ka hüljes (vt lähemalt Maldre 2003a). Tarandkalmetest on leitud ka hobuste (Maldre 1998: 206) ja koerte luid. Mõlemad on enamasti esindatud üksikute luudega ja isendeid on vähe. See teeb aga nende luude kalmetesse panustamise raskemini mõistetavaks. Nagu teame, kuulus hobune Eesti ala ja kogu Põhjala elanike toidusedelisse kuni ristiusu vastuvõtmiseni (Maldre 1998: 206), seega võivad üksikud hobuseluud kalmes viidata hobuse söömisele peietel. See on ka seni peamine interpretatsioon loomaluude esinemisele Eesti kivikalmetes: tegemist on kas peie- või mälestussöömingu jäänustega või on loomi või loomade osi ohverdatud kalmesse surnutele. Kas see võib selgitada ka koeraluude esinemist kivikalmetes? On ju koeradki seal enamasti esindatud vaid üksikute luudega. Koerte söömisest on küll vähem andmeid, samas ei ole see aga võimatu (Boessneck \& Driesch 1979: 395). Ka on hobuste ja koerte arv tarandkalmetes enamasti sarnane ja võib viidata mõlema loomaliigi sarnasele kasutamisele peie- ning matuserituaalides.

Siiski on meil tarandkalmete koera- ja hobuseluuleidude mõistmiseks vähe andmeid ja märksa põnevama analüüsi võimalust pakuvad (koos teiste allikatega) mõnevõrra hilisema perioodi - viikingi-ja hilisrauaaja - eelkõige Lääne- ja Saaremaa kivikalmed.

\section{Viikingi- ja hilisrauaaegsed koeramatused}

Nagu nägime, ei olnud koeraluud kalmetes tundmatud varasematelgi perioodidel, kuid viikingiajal näib olevat aset leidnud muutus koerapidamises ja koera rollis inimeste hulgas.

Üks olulisemaid ja huvitavamaid kalmerühmi selle probleemi juures on Piila viikingiaegne kalmistu Põhja-Saaremaal (Mägi \& Allmäe \& Maldre 1997; Mägi \& Rudi 1999). Uuritud kalmed koosnesid umbes $0,5 \mathrm{~m}$ kõrgusest kividest laotud ringmüürist, mille keskele oli maetud osa tugevasti põletatud surnu luid ja tuleriidal olnud esemed (Mägi \& Allmäe \& Maldre 1997: 104). Erinevalt varasemast loomaluude leidumustest oli seal üsna vähe kitse-, lambaja veiseluid. Ka hobuseluid leidus vaid üksikuid. Seega olid need luud, mis võiksid pärineda peiesöömadest. See-eest leiti aga koeri, kusjuures nad olid nüüd maetud terviklikumalt, mitte enam üksikute luudena. Kõik koerad leiti kiviringkalmest, kuhu oli maetud 
üks inimene, suure tõenäosusega mees. Ühise tunnusena olid kõik koeraluud ka põletatud. Intrigeeriv on, et mõnest kalmest leiti koeraluid märksa rohkem kui inimluid.

Piila II kalme on 4,5 m läbimõõduga kiviring arvuka leiumaterjaliga. Muude leidude hulgas oli loomapeakujuliste otstega käevõru. 1000.-1050. aastasse pKr dateeritud kalmesse oli maetud mees (Mägi \& Allmäe \& Maldre 1997: 110). Enamik osteoloogilisest materjalist kuulus koerale, vähemal määral olid esindatud ka jänes ja kits/lammas. Selle kalme koera puhul oli võimalik välja selgitada tema kasv - turjakõrgusega 55-65 cm kuulus ta kindlasti suurte koerte hulka (Mägi \& Allmäe \& Maldre 1997: 106). Et leitud koeraluud olid põlenud hoopis vähemal määral kui inimluud, võib arvata, et koer oli põletatud eraldi tuleriidal.

Piila III kalme oli märksa väiksem, läbimõõduga vaid $2-3 \mathrm{~m}$ ja kuulus samuti mehele. Loomaluid leiti kalmest vähe, lisaks kahele koerahambale hobusehammas ja kaks veisehammast. Oletati, et selle kalme koer on põletatud mehega samal tuleriidal (Mägi \& Allmäe \& Maldre 1997: 106).

Piila V kalme koosnes $4 \mathrm{~m}$ läbimõõduga kergelt ovaalsest kiviringist, mille lääneküljel oli $75 \mathrm{~cm}$ laiune ava (joonis 2), mida interpreteeriti kui sissepääsu kalmesse (Mägi \& Rudi 1999: 41). Enamvähem kiviringi keskel leiti 0,5 m läbimõõduga ala, kuhu olid asetatud põlenud luud ja tugevasti põlenud esemed, millest äratuntav

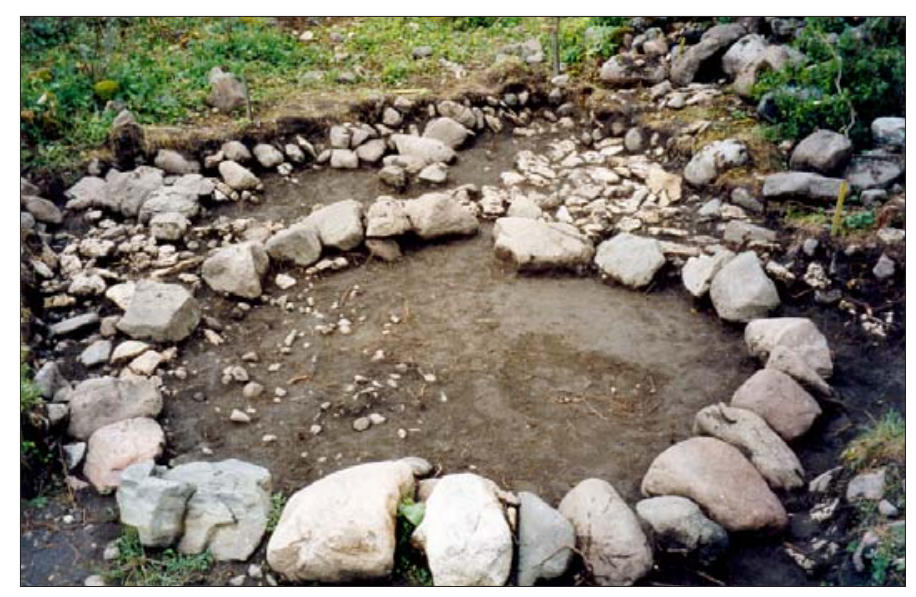

Joonis 2. Piila Vkiviringkalme välismü̈̈r. Marika Mägi foto. 


\section{Tõnno Jonuks}

oli vaid rihmajagaja. Lisaks leiti kalmest kaks täidisekividest nuga, mida peeti aga hilisemateks ohverdusteks (Mägi \& Rudi 1999: 43). Rihmajagaja ja keraamika järgi dateeriti kalme 10.-11. sajandisse. Suurem osa kalmest leitud luudest kuulus koerale ja väheste leitud inimluude põhjal ei olnud võimalik määrata maetu sugu.

Teise olulise piirkonnana Saaremaa kõrval kerkib esile Läänemaa ja selle 10.-13. sajandi konstruktsioonideta kivivarekalmed (Mandel 2003). Sealsetes kalmetes on koeraluud mõnevõrra esindatud küll juba varasemal perioodil, kuid eriti selgesti avaldub koera tähtsustamine just alates 10. sajandist. Iseloomulik on, et sarnaselt Saaremaa kiviringkalmetele olid leitud koeraluud enamasti seotud mõne konkreetse põletus- või matuselaiguga ulatuslikuma kalmekivistiku sees.

Maidla II kalmest leiti ühtekokku vähemalt kuue koera luid, millest enamik oli koondunud matuselohkude juurde või nende sisse. Suurem osa koeraluudest oli põletatud, ehkki leiti ka põletamata luufragmente. Matustega õnnestus kindlamalt kokku viia kaks koera. Neist esimene oli seotud 20-35-aastase mehe matusega, teine aga kuni 35-aastase naisega (Mandel 2003: 58).

Ehmja kalmest leiti vähemalt kahe koera luud. Neist ühe luud paiknesid kompaktse kogumina ja sellega võis seostada põhimõtteliselt kaht põletusmatuse kompleksi: kuni 40-aastast täiskasvanut või last. Ülejäänud koeraluud olid aga kalmes hajali laiali (Maldre 2003a: 270).

Kirbla kalme põletamata, valdavalt veiseluude hulgas eristati tõenäoliselt kahe koera põletatud luud. Neist üks kompleks asus kahe põletusmatuse, täiskasvanud naise ja lapse matuste läheduses (Maldre 2003a: 269).

Uugla I kalme loomaluudest õnnestus määrata ainult koeraluid, mis kõik olid põletatud. Valdav enamik luudest leiti II matuselaigust, kuhu oli maetud 20-35-aastane inimene, kelle sugu ei ole õnnestunud kindlaks teha (Maldre 2003a: 269).

Meie lähiümbruses oli koerte matmine viikingi- ja hilisrauaajal levinud mitmel pool. Esimesed eraldi koeramatused ilmusid Skandinaavias juba rooma rauaajal, kuid levisid laiemalt vendeliajal ja saavutasid suurima arvukuse viikingiajaks. Tähelepanuväärne on, et Skandinaavia koeramatused on levinud ennekõike Ida-Rootsis Mälari ümbruses, kuid neid esineb siiski ka Skånes ja Taanis, vähem EdelaSoomes (Makiewicz 2000). Koeri on üsna tihti maetud ka Koiva liivlaste kääbastesse, näiteks Krimuldas (Tõnisson 1974: 54-64), kusjuu- 
Tõnno Jonuks

res leitud koeraluud kuulusid tõenäoliselt suurtele, tänapäeva lambakoertele sarnanevatele loomadele (Tõnisson 1974: 56).

\section{Koerakujukesed}

Koerte tähtsustamisele viitavad ka kalmetest leitud koerakujukesed. Ehkki seni on neid teada kõigest neli, esindavad nad huvitavat ja omapärast leiuliiki.

Ehmja kalme 7.-8. sajandisse dateeritud koerakujuke leiti kalme segiküntud osast (joonis 3). Pronksist kujuke on $4 \mathrm{~cm}$ pikkune ja $3 \mathrm{~cm}$ kõrgune. Esi- ja tagajalad on ühes tükis, eraldi esile tõstmata, keha on lameda plaadi kujuline ja saba on kujutatud seljale kaarduvana. Kujukese kael on suhteliselt lai, selle mõlemal küljel on ornamendiks kaks ringi ja punktiga motiivi. Koera kõrvad on kujutatud peaga risti olevatena ning silmad koosnevad taas ringist ja punktist. Koera kõhu all on plaadike, mis markeerib peenist. Mingit ripatsi kinnitusaasa kujukesel ei ole - ilmselt ei ole tegemist ehteasjaga klassikalises mõistes.

Samalaadne koerakujuke, millel ei ole ripatsiaasa, leiti Kõmsi kalmest (joonis 4). Ka sellel $3 \mathrm{~cm}$ pikkusel kujukesel on esi- ja tagajalad ühes tükis. Erinevalt eelkirjeldatud kujukesest on selle koera

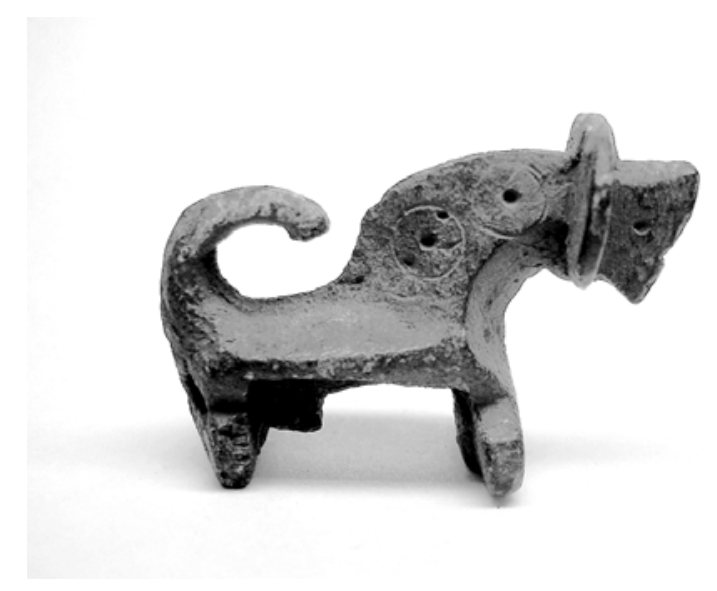

Joonis 3. Ehmja kalmest leitud pronksist koerakujuke (AM 554: 777). 


\section{Tõnno Jonuks}

stiliseeritud keha kujutatud ümaramana ja saba on lühem. Olulisim erinevus aga on see, et kõnealune kujuke on pigem kahemõõtmeline, ehkki töödeldud mõlemalt küljelt. Silm on koeral kujutatud kühmukesena ning mõned koonu elemendid - avatud suu ja kaarjalt üleskeerduv nina - sarnanevad stiliseeritud Jellinge'i stiilile, mis võib aidata dateerida kujukest 10. sajandisse. Mati Mandel on oletanud, et sellist 7,97 g raskust loomakujukest võidi kasutada kaaluvihina (Mandel 2003: 88).

Maidla II kalmest on teada kaks pronksist koerakujukest (joonis 5). Neist esimene leiti 9. leiukompleksist kalme kaguservast koos pandla, pronksnaastude, savinõukildude ja pronksesemete katkenditega (Mandel 2003: 48). Mati Mandel on kujukest interpreteerinud hobusena (Mandel 2003: 48), kuid see sarnaneb silmanähtavalt Ehmja koeraga. Ka siin on keha kujutatud koosolevatele esija tagajalgadele toetuva lameda plaadina, mille peale kaardub saba. Sarnaselt Ehmja kujukesele on ka Maidla koera kael lai ja kõrvad eemalduvad sellest risti kahele poole. Erinevana on Maidla kujukese kael kaunistatud üleni lohukestega, millest üks, eraldiolev on läbiv ja seda on ilmselt kasutatud kinnitusaasana. Ka ei ole Maidla kujukesel eraldi markeeritud silma ja tema koon on avatud pigem sarnaselt Kõmsi kujule. Lühikesed jalad, seljale kaarduv tugev saba ja peaga risti olevad kõrvad viitavad Maidla koera puhul siiski pigem koerale kui hobusele.

Teine Maidla kalme koerakujuke (joonis 6) leiti kahe põletuslaigu vahelt kalme loodeosast ja seda ei olnud võimalik seostada matuste ega muu kompleksiga. Ka selle koera puhul on esi- ja tagajalad kujutatud koosolevatena, keha ja pea on ümarad, kõrvu ja silmi eraldi markeeritud ei ole ning erinevalt teistest on kujuke märksa realistlikum. Erineb ka selle kujukese saba, mis on jalge vahel ja kaardub paremalt küljelt üles, samuti on kuju seljal eraldi riputusaas.

Skandinaavia viikingiaegseid koerakujukesi on teada vähe. Näiteks Ekhammeri naisematusest leitud väikest koerakujukest peetakse hoopis sõle küljest murdunuks ja seejärel amuletina kasutatuks (Zeiten 1997: 15).

On näha, et alates noorema pronksiaja kivikirstkalmetest kuni viikingiajani on koer olnud kalmetes harva - need on üksikud ja enamasti põletamata luud. Alates 9.-10. sajandist on aset leidnud muutus: koeri on hakatud põletama ja panema kalmesse koos inimese matusega. Põhimõtteliselt sarnane areng on aset leidnud ka 
Tõnno Jonuks

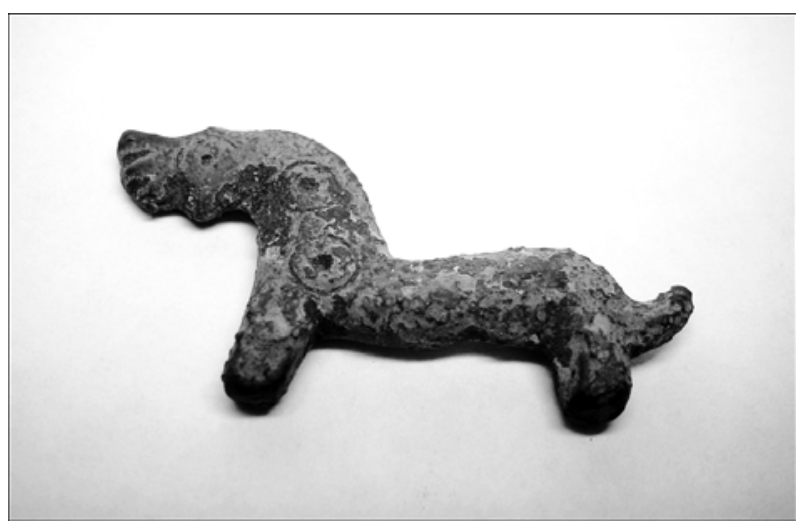

Joonis 4. Kõmsi kalme pronkskujuke (AM 510: 180).

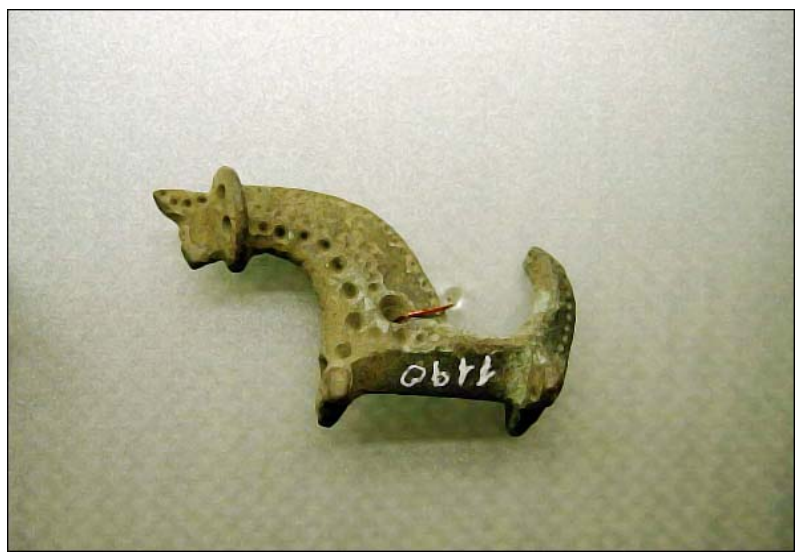

Joonis 5. Maidla II kalmest leitud koerakuju (AM 580: 1190).

Skandinaavias, kus rahvasterännu ajal on põletatud koeri kalmes veel vähe, peamiselt ilmuvad nad vendeliajal (vt Gräslund 2004). Sealtpeale jääb koer sarnaselt Eestile ka Skandinaavias peamiseks põletatud loomaks eelkõige 10.-11. sajandi kalmetes. Ehkki põletatud loomade luid on raske analüüsida, on tõenäoline, et tuleriidale on pandud siiski terve koer ja põletatud koos inimesega, kuid mõnikord on põletatud koer ka eraldi ja tema põletatud luud on 


\section{Tõnno Jonuks}

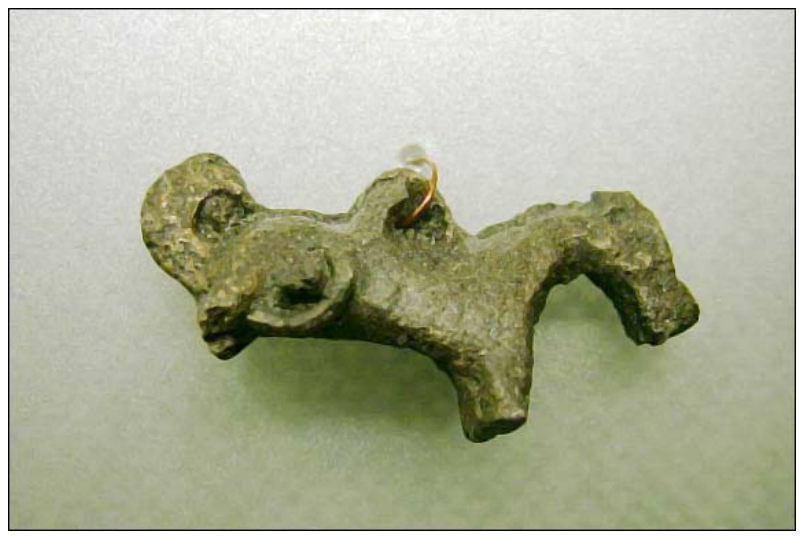

Joonis 6. Maidla II kalmest leitud koerakuju (AM 580: 5865).

kalmesse pandud koos põletatud inimesega - seega on need omavahel seotud.

Tõsi, alati ei ole võimalik koeramatust kalmes siduda mõne konkreetse matusega ei Eestis (Maldre 2003a: 275) ega mujal (Makiewicz 2000: 227). Kui koeramatust on võimalik inimesega kokku viia, esineb koer nii mehe- kui ka naisematustes, ehkki tundub, et meestele on koeri sagedamini kaasa pandud. Samasse aega põletatud koeramatustega võib ilmselt dateerida ka pronksist koerakujukesed. Kuigi Ehmja kujuke on dateeritud märksa varasemaks (7.8. sajandisse), on tema leiutingimused ebaselged ja ka stiililiselt sobib Ehmja koer kokku pigem 10.-11. sajandisse dateeritud koerakujudega.

\section{Kirjalikud allikad muinasaegsete koerte kohta}

Mõningal määral leidub teateid koertest ka kõnealust piirkonda kajastavates kirjalikes allikates. Tuntuim ja kuulsaim on ibn Fadlani kirjeldus viikingi matuserituaalist Volgal, kus koer raiuti koos teiste ohvriloomade (kahe hobuse, kahe lehma, kuke ja kanaga) pooleks ja pandi matuselaeva, mis hiljem põletati (AbuChacra 2004: 48). Koeri on Skandinaavia kontekstis mainitud ohvriloomana ka Uppsala kuulsa templi kirjelduses teiste loomade 
hulgas rippumas ümber templi (Adam IV:27). Bremeni Adama kroonika IV raamatu 19. peatükis on kirjeldus alanitest või albanitest, kes krooniku Solinuse refereeringu järgi kasutavad koeri lahingus:

[---] nende keelt nimetatakse wizzi ja nad on kalgi südamega ogardid ning nad sünnivad hallide juustega. Nende maad kaitsevad koerad. Millal iganes alanid peavad võitlema, seavad nad oma koerad võitlusjoonele (Adam IV: 19).

Skandinaavia keskaegsetes kirjalikes allikates on koeri mainitud üsna tihti. Sageli esineb koer religiooniga seonduvates kontekstides alates Heli valvurist Garmrist ja lõpetades koerte ohverdamise kirjeldustega (vt lähemalt Gräslund 2004).

Ka kroonik Henrik on maininud Liivimaa kroonikas koeri eestlaste ohvriloomana (LHC: XVI 4), ehkki vähem kui kitsi, lambaid ja veiseid. Interpretatsiooniks on kroonika kirjeldus aga keeruline. Selles räägitakse Turaida linnuse piiramisest ja sellest, et sealsed liivlased ohverdavat jumalatele tänutäheks sakslaste piiramistorni ümberkukkumise eest koeri ja sikke (canes et hircos). Seejärel visanud liivlased aga ohvriks toodud loomad hoopis linnusest "kristlaste pilkamiseks" välja. Miks käitusid liivlased oma ohvriloomadega nii ebatraditsiooniliselt, jätab Henrik seletamata. Ehk pidas kristlasest kroonik ohverdamiseks hoopis midagi, mis seda tegelikult ei olnud? Ohvriloomade linnusest välja piiravate vaenlaste ette loopimine on aga kahtlemata ebaharilik käitumine.

\section{Interpretatsioonid}

Kui asulate ja linnuste materjalis on koeri võetud ennekõike inimkaaslejatena (vt Maldre 2003b; Boessneck \& Driesch 1979), siis kalmematerjali on tõlgendatud teistel alustel. Ehkki koerad on etendanud Eesti viikingi- ja hilisrauaaja elanike maailmavaates ilmselt olulist rolli, on nende tähenduse üle seni vähe arutletud. Järgnevalt esitan mõned enimlevinud interpretatsioonid Eestist ja maailmast ning püüan neid sobitada Eesti arheoloogilise materjaliga.

On selge, et koerale ei ole võimalik omistada mingit üht ja kõikehõlmavat tähendust. Koertele ja ka paljudele teistele feno- 


\section{Tõnno Jonuks}

menidele on omistatud läbi aegade erinevates piirkondades üsna erinevaid rolle ja neisse on suhtutud erinevalt. Teinekord isegi ühel ja samal ajal, ühes ja samas kultuuris (vt näiteks Kitchell 2004).

Jälgides koera puudutavaid interpretatsioone usundiloolistes uurimustes, kerkib ühe esimese ja enimlevinud seosena üles koer kui teispoolusese valvur ja ka teispoolsuse sümbol (Gräslund 2004; Nedoma 2000: 216; vt ka Bächtold-Stäubli \& Hoffmann-Krayer 1987: 472 ja seal viidatud kirjandus). Tuginedes valdavalt Euroopa mütoloogiatele on uurijad tõmmanud paralleele Kreeka Hadese valvuri Kerberose ja Skandinaavia Garmriga. Tegemist ongi valdavalt Euroopa usundiloolaste ja mütoloogide interpretatsioonidega, mis tuginevad peamiselt kirjanduslikele allikatele ja vähem arheoloogiale (Davidson 1998; Olsen 2000: 89). Ka on selliste käsitluste puhul kasutatud arheoloogilist allikmaterjali pigem illustreerimiseks ja väite kinnitamiseks, mitte hüpoteesi allikana (Lurker 1987: 396). Mitmel põhjusel ei tundu aga see sügavalt sümbolistlik käsitlus sobivat seletama Eesti ja kogu Läänemere ümbruse arheoloogilist materjali. Tekib rida rituaalidega seonduvaid küsimusi. Miks põletada teispoolsuse valvur ja anda see maetule kaasa? Samas ei ole põletatud kõiki koeri ja mõned neist on asetatud kalmesse ka laibana. Lisaks on koer maetud surnu kõrvale väga harva. Muidugi võib spekuleerida teemal, et surnule kaasa pandud koer oli ohver, kes võis aidata surnul ületada surmakoera valvatavat piiri ja jõuda kergemini teispoolsusesse (Lurker 1987: 397; Davidson 1998: 51). Samas ei ole meie rahvausundis sõnagi koerast kui surmavalla valvurist ning niivõrd hilisest fenomenist, nagu seda on viikingiaegne tugev koerte tähtsustamine, oleksid pidanud säilima mingidki jäljed.

Teine, samuti peamiselt usundi ja mütoloogia uurijate interpretatsioon on sõjakoer, seda eriti germaani kultuuriruumis, kus lisaks huntidele on arvatud peajumal Wodani/Oðinni kaaskonnas jooksvat ka koeri (Lurker 1987: 397). Selles interpretatsioonis on samastatud koer ja hunt ning sealtkaudu on koerigi seostatud poolmütoloogiliste sõdalaste úlfheðnarite ehk hundinahksetega. Tegemist oli kuulsate berserkrite ehk karusärklaste kaaslastega, kes võisid end lahingus samastada hundiga. Kaudselt assotsieerub selle interpreteerimisvõimalusega babüloonia-assüüria kultuuriruumi puudutav tõlgendus koerast kui lahingus kasutatavast sõjakoerast (Göhde 1998: 20-28). Sealsete allikate (pitsatid, raidtahvlid) 
võrdlus Eesti omadega aga ei luba interpretatsiooni Eesti alale üle kanda. Ainus kirjalik tõend koerte kasutamisest lahingus Põhjala piirkonnas on pärit ülalosundatud Bremeni Adama kroonikast. Mõningaid kahtlusi tekitab kirjelduse põhinemine Solinuse refereeringul. Kogu wizzide lugu on peetud ka fantaasiarikkaks väljamõeldiseks ala kohta, millest antiikautorid teadsid kas vähe või üldse mitte midagi (Adam 2002: xxxi)

Mõningad nähtused, näiteks koerad enamasti rikkamate meeste kalmistutes, nn sõdalaste matustes, võivad tõesti viidata koera seosele sõjaga. Samas ei ole Eestist registreeritud veel ühtegi autentset lugu ei úlfheðnarist ega berserkrist, lisaks ei pruugi relvad kalmetes näidata, et maetu oli isiklikult vägev sõdalane. Pigem langes selline surmajärgne kohtlemine osaks rikkamale ja mõjuvõimsamale eliidile, kes ise väga tihti võitluses ei pruukinudki osaleda (Mägi 2003: 25). Ka võib koer seonduda naisega (nt Maidla ja Kirbla kalmeleiud (Maldre 2003a: 269)). Pealegi ei ole Eesti kalmetest minu teada leitud veel ühtegi määratud hundiluud, mida sellise kontseptsiooni puhul võiks aga leiduda. Seda võimalust ei kinnita ka Eesti kalmete koerakujukesed, mille saba on koeralikult seljal rõngas, mitte hundilikult sorgus. Ja vast peamine, mis ei luba seostada koera kalmes ja poolmütoloogilist hundikujulist sõdalast - úlfheðnarid esindavad oma hundimatkimises ennekõike metsikust, ohjeldamatust ja spontaanset raevu, samas kui kodustatud koer on või vähemalt peaks olema selle kõige vastand.

Levinud usundilooline interpretatsioon seostab loomafiguuri erinevate mütoloogiliste ja maagiliste nähtustega, kusjuures kindlalt ei toetata ega välistata ühtegi. Nii on näiteks Skandinaavia hobusekujutisi seostatud aaside ohvrilooma, Oðinni Sleipniri, šamaani abivaimu ja loomulikult ka viljakus- ja surnukultusega (vt Zeiten 1997: 13-14). Sarnaselt, seostatuna mitmete erinevate nähtustega, on interpreteeritud ka koeri (Gräslund 2004). Eelnevaga seonduvad ka koerte ohverdamise tausta kohta välja pakutud usundiuurijate mitmesugused põhjused alates sümboolsest puhastusideest ja lõpetades koera kui jumalatele sõnumi viijaga (vt lähemalt Lurker 1987: 396).

Ühest küljest on selline metodoloogiline lähenemine kindlasti vajalik. Ei ole ju võimalik seletada laialt levinud nähtust, näiteks koera, kes esineb erinevates kontekstides arheoloogilistes matustes, mütoloogilistes lugudes, ohvritoomiste kirjeldustes jne, ainult 


\section{Tõnno Jonuks}

ühe interpretatsiooniga. Teisest küljest: kas kõik need avaldumisvormid peavad üldse olema üksteisega seotud? Kas ei ole tõenäolisem, et osa fenomene, mis on inimühiskonnale olnud olulisemad, on esindatud mitmes eri aspektis erineva sümboolsusega? Seega ei pruugi koer arheoloogilises matuses ollagi seotud koeraga mütoloogilises tekstis.

Mõnevõrra on arutletud ka teemal koer kui hauavalvur, kus koera hauda kaasapanemine väljendab sümboolselt haua enda valvamist. Koera funktsiooniks on maetu hauaröövlite eest kaitsmine või hoopis tagasipöördumise takistamine. Esimese võimaluse (kaitse hauaröövlite vastu) kasuks räägivad viikingiajal alanud rikkalike panustega matused, mis loomulikult meelitasid ka hauaröövleid. Viikingi- ja hilisrauaaja kontekstis on hauaröövimine ka arheoloogide poolt aktsepteeritud (Mandel 2003: 148; Tamla 1996: 223). Ka surnu koduskäimise ja surnutõrjemaagia kohta on leitud arvukalt tõendeid (vt nt Kulmar 1994). Nende mõlema seletuskatsega, mis apelleerivad üsna laiadele ja üldinimlikele põhjustele, jääb aga vastamata küsimus, miks tekkis või tugevnes selline kontseptsioon suhteliselt piiratud ajal (10.-11. sajandil) ja Eesti puhul ka piiratud territooriumil (Saaremaal ja Lääne-Eestis). Euroopa kontekstis on tegemist küll laiema fenomeniga, kuid siin põrkame hoopis teistsugusele materjalile - koeramatustele, mis levivad erinevates piirkondades vahetult enne kristluse laiemat levimist. Selle juurde aga allpool. Kasutades nii laiapõhjalisi seletusi, nagu koer kui haua või surnu valvur, oleks põhjust eeldada koerte sel eesmärgil kalmes kasutamist märksa pikema perioodi jooksul ja ka laiemal territooriumil.

Eesti ja naabermaade arheoloogid tõlgendavad koera ja teiste loomade hauda panustamist ohvrina surnule või ohvrina jumalatele (Makiewicz 2000: 222). Kui enamiku loomaluude, valdavalt kits/lammas, veis ja siga, puhul on peie- ja mälestussöömad tõenäoline interpretatsioon (mida kinnitab ka nende luude mittepõletamine), siis koerte puhul ei peeta enamasti söömist tõenäoliseks ja seetõttu tõlgendatakse koeri üksnes ohvrina surnule (Maldre 2003a: 278). Kahjuks ei mõtesta uurijad enamasti lahti, mida peetakse silmas surnule koera ohverdamise all, ja tundub, et tihti peetakse selle mõtestamist ka võimatuks. Kus vähegi on ohverdamise tähendust püütud konkreetsemalt avada, seal on kõlama jäänud kaks võimalust: tegemist on kas ohvri kui teemoonaga teispoolsusesse või ohvri kui millegagi, mida surnu saab 
teispoolsuses kasutada. Tuleriidal koos peremehega põletatud koer ei tule suure tõenäosusega teemoonana kõne alla. See seletus võib kehtida teiste, peamiselt "söögiloomade" luude kohta. Samuti ei sobi see interpretatsioon seletama pronksist koerakujukesi. Teine seletus (teispoolsuses kasutamine) tekitab aga küsimuse, miks valiti just koer. Oli ju sealilmas ilmselt vaja ka teisi loomi. Paljud uurijad on oletanud, et Eesti elanike uskumuste järgi jätkus elu pärast surma sarnaselt maapealsele elule (Valk 2001: 92). Seega oli vaja ka tööloomi. Need aga on kalmetes esindatud vaid üksikute luudega ning üldjuhul arvatakse, et needki on pigem toidujäänused.

Viimastel aastatel on Euroopa arheoloogias levinud interpretatsioon jahikoerast kui jahiloomast, kes on seotud ennekõike ühiskonna eliidiga (Makiewicz 2000: 227 ja seal viidatud kirjandus). Üsna laialt levinud mudeli kohaselt kujunes jahipidamine aja jooksul eliidi pärusmaaks ja muutus paljudele ühiskonna tavaliikmetele raskesti kättesaadavaks. Jahipidamise marginaalsust elatusvahendite hulgas näitavad ka asulate osteoloogilise materjali uuringud, kus metsloomaluid esineb üsna vähe. Tõsi, ka kalmetes on metsloomaluid vähe, kuid see näitabki, et jahipidamine oli tuntud, kuid ei kuulunud ühiskonna enamiku elatusvahendite hulka.

Teiseks eristab koera ülejäänud loomadest tema põletamine tuleriidal. Kui valdav enamik lihaloomade luudest on kalmes põletamata ja sattunud sinna ilmselt tõesti peie- või mälestussöömade käigus või tänu surnule teemoona panustamisele, siis koer on põletatud sarnaselt (tõenäolisele) peremehele, seega on koer sarnaselt oma peremehele maetud kalmesse, mitte sinna lihtsalt panustatud. Seega võikski üks viikingi-ja hilisrauaaja koeramatuste interpretatsioon olla koer kui staatusloom, mille praktiliseks väljundiks võis olla surnule kalmesse kaasa pandud jahikoer. Minu arvates, arvestades koerakujukeste ja eraldi koeramatuste ilmumist kalmetesse viikingiajal, tundubki usutavam, et koer on pigem seotud surnu sotsiaalse positsiooni, seega tema rikkuse ja võimuga. Seega võib interpreteerida viikingiaegseid koeramatuseid ja koerakujukesi kui surnule teispoolsesse ellu kaasa antud sümboleid. Kindlasti ei ole õige näha hauda surnuga kaasa pandud koeras pelgalt jahikaaslast, kes on surnud peremehele lojaalsusest kaasa pandud (samal teemal vt Gräslund 2004). Pigem on koer maetu sotsiaalse positsiooni indikaatorina üks komplekse usundilise pildi aspekt. 


\section{Tõnno Jonuks}

Oluline on ka koeramatuste ilmumine kalmetesse ajal, mil kõikjal Põhjalas, sh Eestis, on toimunud liikumine rikkalikumate ja arvukamate esemetega matuste suunas. Anne-Sofie Gräslund on sidunud Euroopa koeramatused ristiusu levikuga ja juhtinud tähelepanu, et langobardide, frankide, alemannide ja anglosakside koeramatused kuuluvad põhiliselt perioodi 400.-700. aasta, saksidel ja friislastel 600.-800. aasta ning Skandinaavias 600.-1050. aasta (Gräslund 2004: 170), seega aega mõnisada aastat enne kristluse valitsema pääsemist. 10.-12. sajand on Eestis lisaks ka periood, mil esineb nii kivikalmeid kui ka maa-aluseid laibamatuseid, mille panuste iseloom näib viitavat uskumusele teispoolsusest kui eraldi paigast, kus jätkus surnute maisele elule sarnane eksistents, mis tingis haudadesse lisaks varasematele ehetele ja individuaalsetele esemetele "päris" hauapanuste, nagu tööriistad, relvad jmt, panustamise. Seega võiks koer kalmes esindada sama usundilist kontseptsiooni nagu rikkalikud Raatvere sepamatused, poleemikat tekitanud Iila mehematus, arvukad sõjameeste matused paljude relvadega jne (vt Jonuks 2003). Arvestades selle perioodi hauapanuseid, kus lisaks ehetele on esindatud tööriistad ja relvad ning maetule tervena kaasa pandud koerad, võib arvata, et teispoolsust kujutati maisele maailmale sarnasena, kuid mitte igas selle aspektis. Pigem võiks uskuda, et see, mida näeme läbi matmisviiside ja hauapanuste, peegeldab ühe osa, ilmselt ühiskonna eliidi kontseptsiooni teispoolsusest. Lisaks ei peegelda see kontseptsioon kindlasti mitte reaalset maist elu, vaid ideaali, milline elu peaks olema. On tõenäoline, et selles võis olla oluline osa pidustustel ja nii ei kajasta teispoolsus mitte elavate maailma harilikku elu, vaid pigem midagi erakordset.

Siinkohal saab tõmmata paralleeli Skandinaavia Valhallaga. Peeti ju sedagi eraldi surmajärgseks maailmaks, kus eksistents jätkus, kuid mitte täpselt sel viisil nagu enne surma. Lisaks on ka kujutlust Valhallast dateeritud Skandinaavia usundis suhteliselt hiliseks fenomeniks (Sawyer \& Sawyer \& Wood 1987: 14), mille levikuaeg kattub Eesti arheoloogilises materjalis nii rikkalikult panustatud matuste ilmumise kui ka koerte kaasapanemisega surnule. Ka Eesti rahvapärimuslik Teine Ilm peegeldab ennekõike ideaali elust ega ole selle surmajärgne täpne vaste. Ja sellises teispoolsuses oli oma ja oluline roll ilmselt ka koertel, kes saatsid Lääne-Eesti ja Saaremaa ülikuid nii pidustustel kui jahil. 
Tõnno Jonuks

\section{Kirjandus}

Abu-Chacra, Faruk 2004. Viikingit arabin silmin: "Ibn Fadlan" vuodelta 922 = Vikingarna $i$ en arabs ögon : "Ibn Fadlan" från år $922=$ Vikings through Arab eyes : "Ibn Fadlan” A.D. 922. Helsinki: Ammatour-Press.

Adam 2002 = History of the Archbishops of Hamburg-Bremen. Adam of Bremen. Tschan, Francis J. (tõlk \& komment) \& Reuter, Timothy (eessõna ja bibliogr). Records of Western civilization. New York: Columbia University Press.

Boessneck, Joachim \& Driesch, Angela 1979. Die Tierknochenfunde mit ausnahme der Fischknochen. Boessneck, Joachim et al. (toim). Eketorp Befestigung und Siedlung aufÖland/Schweden:Die Fauna. Stockholm: Royal Academy of Letters, History and Antiquities, lk 24-421.

Bächtold-Stäubli, Hanns \& Hoffmann-Krayer, Eduard (koost) 1987. Handwörterbuch des deutschen Aberglaubens 4: Hieb- und stichfest Knistern. Berlin \& New York: Walter de Gruyter, lk 470-490.

Davidson, Hilda Roderick Ellis 1998. Roles of the Northern Goddess. London et al.: Routledge.

Eriksson, Gunilla \& Lõugas, Lembi \& Zagorska, Ilga 2003. Stone Age hunter-fisher-gatherers at Zveinjeki, northern Latvia: Radiocarbon, stable isotope and archaeozoology data. Before Farming: The archaeology and anthropology of hunter-gatherers 1 (2), Bristol: Western Academic \& Specialist Press, lk 47-67 (vt ka http://www.waspjournals.com/journals/ beforefarming/journal_20031/abstracts/index.php - 15. detsember 2005).

Gräslund, Anne-Sofie 2004. Dogs in grave - a question of symbolism? Frizell, Barbro Santillo (toim). PECUS: Man and animal in antiquity: Proceedings of the conference at the Swedish Institute in Rome, September 9-12, 2002. The Swedish Institute in Rome: Projects and Seminars 1. Rome, lk 167-176 (http://www.svenska-institutet-rom.org/pecus/graslund. pdf - 15. detsember 2005).

Göhde, Hildegard 1998. Vom Hirtenhund zum Göttersymbol:Die Bedeutung des Hundes im Alten Mesopotamien vom Beginn bis zum Untergang. Textteil. Inaugura-Dissertation zur Eralngung des Doktorgrades der Philosophischen Fakultät der Westfälischen Wilhelms-Universität zu Münster (Westfahlen). Hannover: Westfälische Wilhelms-Universität zu Münster.

Jaanits, Lembit \& Laul, Silvia \& Lõugas, Vello \& Tõnisson, Evald 1982. Eesti esiajalugu. Tallinn: Eesti Raamat.

Jonuks, Tõnno 2003. Eesti metalliaja usundi põhijooni: Magistritöö. Käsikiri Tartu Ülikooli raamatukogus. Tartu: Tartu Ülikooli filosoofiateaduskonna ajaloo osakond. 


\section{Tõnno Jonuks}

Kitchell, Kenneth F. jun. 2004. Man's best friend?: The changing role of the dog in Greek society. Frizell, Barbro Santillo (toim). PECUS: Man and animal in antiquity: Proceedings of the conference at the Swedish Institute in Rome, September 9-12, 2002. The Swedish Institute in Rome: Projects and Seminars 1. Rome, lk 177-182 (http://www.svenska-institutetrom.org/pecus/kitchell.pdf - 15. detsember 2005).

Kraut, Ants 1985. Die Steinkistengräber von Jõelähtme. Eesti Teaduste Akadeemia toimetised. Ühiskonnateadused = Известия Академии наук Эстонии. Общественные науки = Proceedings of the Estonian Academy of Sciences. Social Sciences 35. Tallinn: Perioodika, lk 348-350.

Kriiska, Aivar 2004. Aegade alguses: 15 kirjutist kaugemast minevikust. Tallinn: A. Kriiska.

Kriiska, Aivar \& Tvauri, Andres 2002. Eesti muinasaeg. Tallinn: Avita.

Kulmar 1994. Eesti muinasusundi vanima kihistuse väe-, jumala- ja hingekujutluste teoloogia: Doktoriväitekiri = Die Theologie der Kraft-, Götterund Seelenvorstellungen der Ältesten Schicht der Estnischen Urreligion: Dissertatsioon. Käsikiri Tartu Ülikooli raamatukogus. Tartu: Tartu Ülikooli usuteaduskonna võrdleva usuteaduse õppetool.

Larsson, Lars 2000. Cemetries and Mortuary Practice in the Late Mesolithic of Southern Scandinavia. Lang, Valter \& Kriiska, Aivar. De temporibus antiquissimis ad honorem Lembit Jaanits. Muinasaja teadus $=$ Research into ancient times 8. Tallinn: Ajaloo Instituut, lk 81-102.

LHC 1982 = Henriku Liivimaa kroonika. Kleis, Richard (tõlk) \& Tarvel, Enn (toim \& komment). Tallinn: Eesti Raamat.

Lurker, Manfred 1987. Dogs. Eliade, Mircea (peatoim). The Encyclopedia of Religion 4: Conc-Ecol. New York: Macmillan Publishing Company \& London: Collier Macmillan, lk 395-397.

Makiewicz, Tadeusz 2000. Hund und Hundegräber: Archäologisches. Beck, Heinrich \& Geuenich, Dieter \& Steuer, Heiko (toim). Reallexikon der Germanischen Altertumskunde 15. 2. tr. New York: Walter de Gruyter, lk 219-232.

Mandel, Mati (koost) 2003. Läänemaa 5.-.13. sajandi kalmed. Töid ajaloo alalt 5. Tallinn: Eesti Ajaloomuuseum.

Maldre, Liina 1998. Hobune Eestis muinas- ja keskajal. Peets, Jüri (koost). Loodus, inimene ja tehnoloogia: Interdistsiplinaarseid uurimusi arheoloogias $=$ Nature, man and technology: Interdisciplinary studies in archaeology. Muinasaja teadus $=$ Research into ancient times 5. Tallinn: Eesti TA Ajaloo Instituut, lk 203-220. 
Maldre, Liina 2003a. Läänemaa kivikalmete arheozooloogiline aines. Mandel, Mati (koost). Läänemaa 5.-13. sajandi kalmed. Töid ajaloo alalt 5. Tallinn: Eesti Ajaloomuuseum, lk 263-286.

Maldre, Liina 2003b. Asva koerte koproliitide arheozooloogiline analüüs. Lang, Valter (peatoim). Eesti Arheoloogiaajakiri = Estonian Journal of Archaeology 7: 2. Tallinn: Teaduste Akadeemia Kirjastus, lk 140-149.

Mägi, Marika \& Allmäe, Raili \& Maldre, Liina 1997. Viking Age graveyard at Piila, Saaremaa. Tamla, Ülle (koost \& toim). Arheoloogilised välitööd Eestis = Archaeological Fieldworks in Estonia. Stilus: Eesti Arheoloogiaseltsi teated 7. Tallinn: Muinsuskaitseamet, lk 99-116.

Mägi, Marika \& Rudi, Armin 1999. New stone circle graves at Piila cemetry, Saaremaa. Tamla, Ülle (koost \& toim). Arheoloogilised välitööd Eestis = Archaeological field works in Estonia. Stilus. Tallinn: Muinsuskaitseamet, lk 39-49.

Mägi, Marika 2003. Eesti ühiskond keskaja lävel. Mägi, Marika (koost \& toim). Eesti aastal 1200. Tallinn: Argo, lk 15-42.

Nedoma, Robert 2000. Hund und Hundegräber: Sprachliches: Etymologisches: Altertumskundliches. Beck, Heinrich \& Geuenich, Dieter \& Steuer, Heiko (toim). Reallexikon der Germanischen Altertumskunde 15. 2. tr. New York: Walter de Gruyter, lk 212-217.

Nilsson Stutz, Liv 2003. Embodied Rituals \& Ritualized Bodies: Tracing Ritual Practices in Late Mesolithic Burials. Acta Archaeologica Lundensia Series in 8: 46. Stockholm: Almqvist \& Wiksell International.

Olsen, Sandra L. 2000. The Secular and Sacred Roles of Dogs at Botai, North Kazakhstan. Crockford, Susan Janet (toim). Dogs through time: An archaeological perspective; proceedings of the 1st ICAZ Symposium on the History of the Domestic Dog, eighth congress of the International Council for Archaeozoology (ICAZ98), August 23-29, 1998, Victoria, B.C., Canada. BAR International Series 889. Oxford: Archaeopress, lk 71-92.

Sawyer, Birgit \& Sawyer, Peter Hayes \& Wood, Ian 1987 (toim). The Christianization of Scandinavia: Report of a symposium. Alingsås: Viktoria Bokförlag.

Tamla, Toomas 1996. Virumaa muinasaeg. Saaber, Kalju (koost). Virumaa: Koguteos. Rakvere: Lääne-Viru Maavalitsus \& Ida-Viru Maavalitsus, lk 206-244.

Tõnisson, Evald 1974. Die Gauja-Liven und ihre materielle Kultur (11. Jahrhundert - Anfang 13. Jahrhunderts): Ein Beitrag zur ostbaltischen Frühgeschichte. Tallinn: Eesti Raamat. 


\section{Tõnno Jonuks}

Valk, Heiki 2001. Rural Cemetries of Southern Estonia 1225-1800 AD. CCC (= Culture Clash or Compromise) Papers 3. Reports 2. Visby \& Tartu: University of Tartu (Gotland University College).

Zagorska, Ilga \& Lõugas, Lembi 2000. The Tooth Pendant Head-Dresses of Zveinjeki Cemetery. Lang, Valter \& Kriiska, Aivar. De temporibus antiquissimis ad honorem Lembit Jaanits. Muinasaja teadus $8=$ Research into ancient times 8. Tallinn: Ajaloo Instituut, lk 223-244.

Zeiten, Miriam K. 1998. Amulets and Amulet Use in Viking Age Denmark. Acta Archaeologica 68 (1997). København: Munksgaard, lk 1-74. 